J-ABDIPAMAS (Jurnal Pengabdian kepada masyarakat)

Vol. 4 • No. $2 \bullet$ Oktober 2020

ISSN : 2581-1320 (Print) ISSN : 2581-2572 (Online)

Homepage: http://ejurnal.ikippgribojonegoro.ac.id/index.php/J-ABDIPAMAS

\title{
INOVASI PENJUALAN BATIK BERBASIS ONLINE DI DESA PASESEH KECAMATAN TANJUNGBUMI KABUPATEN BANGKALAN
}

\author{
Zainal Arifin ${ }^{1}$, Husnul Muasyaroh ${ }^{2}$, Annas Bagus Prasetya3 ${ }^{3}$, Nurus Samsiyati ${ }^{4}$ \\ ${ }^{1}$ STKIP PGRI Bangkalan. Email: zainal@stkippgri-bkl.ac.id \\ 2STKIP PGRI Bangkalan. Email: husnulmuasyaroh311@gmail.com \\ 35TKIP PGRI Bangkalan. Email: annasbp05@gmail.com \\ ${ }^{4}$ STKIP PGRI Bangkalan. Email: smytnurus739@gmail.com
}

\begin{abstract}
Tanjungbumi batik has the privilege of a striking color. This is a characteristic of Madurese people who are known to be brave in combining color choices. In addition, Tanjungbumi batik has art patterns and motifs that depict the activities of fishermen and animals that are encountered while at sea. This pattern describes the lives of some of the inhabitants of Tanjungbumi who become fishermen. Because of the good and varied patterns and colors, it is a shame if it is only sold in the paseseh area (through shops and markets). Based on the results of interviews with batik craftsmen, the batik sold in a week is approximately Rp. 250,000-300,000 so that the income in the village of Paseseh is not optimal. Therefore, the service team will help market batik online, so that the results will be obtained by the public faster. Team made an online buying and selling application called the BBTB application, namely Bumi Batik Tanjungbumi. The name of this application certainly refers to the place of origin of the items being sold, namely batik. The purpose of PKM activities is to change the batik selling system into an online buying and selling application. The result of this PKM activity is the availability of an online buying and selling application that has features including: 1) product information, 2) contact points, 3) payment systems, and 4) simulation of shipping costs.
\end{abstract}

Keywords: Inovation, Batik Tanjungbumi, Aplication

\begin{abstract}
ABSTRAK
Batik Tanjungbumi memiliki keistimewaan pada warna yang mencolok. Inilah ciri khas masyarakat Madura yang dikenal berani memadukan pilihan warna. Selain itu, batik Tanjungbumi memiliki corak dan motif seni yang menggambarkan aktivitas nelayan dan satwa yang di jumpai saat melaut. Pola ini menggambarkan kehidupan sebagian penduduk Tanjungbumi yang menjadi nelayan. Karena corak dan warnanya yang bagus dan variatif, sayang jika hanya dijual di kawasan paseseh (melalui toko dan pasar). Berdasarkan hasil wawancara dengan pengrajin batik, harga batik yang dijual dalam seminggu kurang lebih Rp. 250.000-300.000 sehingga pendapatan di Desa Paseseh belum optimal. Oleh karena itu tim pengabdi akan membantu memasarkan batik secara online, sehingga hasilnya lebih cepat didapat masyarakat. Tim membuat aplikasi jual beli secara online bernama aplikasi BBTB yaitu Bumi Batik Tanjungbumi. Nama aplikasi ini tentunya mengacu pada tempat asal barang yang dijual yaitu batik. Tujuan dari kegiatan PKM adalah merubah sistem penjualan batik menjadi aplikasi jual beli online. Hasil dari kegiatan PKM ini adalah tersedianya aplikasi jual beli online yang memiliki fitur antara lain: 1) informasi produk, 2) kontak hubung, 3) sistem pembayaran, dan 4) simulasi biaya pengiriman
\end{abstract}

Kata Kunci: Inovasi, Batik Tanjungbumi, Aplikasi BBTB 


\section{PENDAHULUAN}

Madura merupakan sebuah pulau yang terletak di timur Pulau Jawa. Pulau Madura memiliki luas 5200 dan hingga awal tahun 2017 tercatat sebanyak 4.097.393 jiwa yang tersebar di empat kabupaten yaitu Kabbupaten Bangkalan, Kabupaen Sampang, Kabupaten Pamekasan, dan Kabupaten Sumenep. Di kabupaten Bangkalan terdiri dari 1.190.129 jiwa yang tersebar di 18 kecamatan, 8 kelurahan, dan 273 desa. Salah satu kecamatan di kabupaten Bangkalan yang terkenal karena karyanya yaitu kecamatan Tanjungbumi. Tanjungbumi merupakan kecamatan yang dikenal karena memiliki karya berupa batik. Salah satu desa yang memproduksi batik tanjungbumi yaitu desa Paseseh. Desa Paseseh ini merupakan desa yang rata-rata masyarakatnya memiliki mata pencaharian berupa memproduksi batik dan bekerja sebagai nelayan dikarenakan kondisi daerahnya yang dekat dengan laut, tapi ada juga beberapa yang menjadi pengangguran. Batik dari tanjungbumi ini disebut juga batik khas Madura, yang telah dikenal oleh masyarakat luas. Batik tanjungbumi memiliki keistimewaan dan menjadi karakteristik produk batik, yaitu warna yang sangat mencolok. Hal tersebut menggambarkan keberanian masyarakat Madura dalam melakukan pemaduan warna. Corak dan motif yang digambarkan dalam batik Madura merupakan aktivitas masyarakat Madura pada umumnya yang berprofesi sebagai nelayan dan hewan-hewan laut yang biasa ditemu saat melaut. Motif batik Tanjungbumi bercerita tentang kehidupan warga Tanjungbumi yang mayoritas adalah nelayan.

Karena corak dan warnanya yang bagus dan beragam, maka sangat disayangkan jika hanya dijual di daerah paseseh saja (melalui toko dan pasar). Berdasarkan hasil wawancara dengan pengrajin batik, batik yang terjual dalam seminggu kurang lebih Rp. 250.000-300.000 sehingga penghasilan di desa paseseh kurang maksimal. UMKM masing kurang berkembang karena belum memanfaatkan media sosial maupun aplikasi sebagai media pemasaran produk (Syahputri, 2018). Oleh karena itu, tim peneliti akan membantu memasarkan batik secara online, sehingga hasil yang akan diperoleh masyarakat lebih cepat. Saat ini, proses penjualan dan pembelian barang di internet sangat digemari oleh masyarakat. Aplikasi jual beli online seperti shopee, buka lapak dan lain sebagainya begitu laris digunakan masyarakat baik itu untuk menjual sesuatu ataupun membeli sesuatu. Aplikasi jual beli online ini juga begitu mudah untuk digunakan sehingga tidak hanya anak-anak muda tetapi juga orang dewasa banyak yang menggunakan aplikasi seperti ini. Oleh karenanya pengabdi membuat aplikasi jual beli online yang bernama aplikasi BBTB yaitu Bumi Batik Tanjungbumi. Nama aplikasi ini tentunya merujuk pada tempat asal barang yang dijual yaitu batik. Tidak jauh berbeda dengan aplikasi online yang sudah ada, aplikasi ini memiliki beberapa fitur di dalamnya, seperti beranda, favorit, keranjang, pesanan dan akun. Tentunya para calon pembeli batik Tanjungbumi harus memiliki akun agar mudah dalam proses pengiriman batik yang dibeli. 
Manfaat menggunakan aplikasi ini tentunya masyarakat yang berada di mana saja, baik luar Madura maupun dalam Madura bisa membeli batik Tanjungbumi langsung tanpa khawatir membeli yang palsu, karena aplikasi BBTB dibuat khusus untuk proses penjualan batik Tanjungbumi. Dengan adanya aplikasi ini, diharapkan semoga batik Tanjungbumi dapat meluas hingga mancanegara dan para pengrajin batik di Tanjungbumi bisa mendapat keuntungan yang lebih banyak, sehingga dapat mengentaskan kemiskinan yang ada di desa Paseseh, Tanjungbumi, Bangkalan. Tujuan kegiatan PKM ini adalah melakukan inovasi penjualan batik Tanjungbumi melalui aplikasi berbasis online.

Online shop sendiri, termasuk dalam kategori E-commerce, dikarenakan dalam transaksi jual beli, aplikasi memberikan keleluasaan kepada pembeli untuk menentukan jenis produk atau jasa yang dibutuhkan terlebih dahulu melalui jaringan yang dapat diakses secara online dan kemudian menetapkan metode pembayaran yang diinginkan sesuai kebutuha (Languyu Novianto, 2015). Saat ini semua aktivtas dan kegiatan pemenuhan kebutuhan masyarakat dilakukan secara online sehigga dikarenakan banyaknya pihak-pihak yang menjual produk dan jasa secara online (Hoga Saragih, 2012). E-commerce tidak dapat dipandang sebagai sebuah toko belaka di dalam media berbeda atau sebagai saluran penjualan baru dengan menggunakan teknologi komunikasi, sebaliknya memberikan perusahaan banyak keunggulan lain seperti saluran distribusi baru, layanan distribusi produk, biaya yang berkurang dan penjualan langsung yang merupakan hal vital untuk bisnis (Sitorus, 2019). Kemudahan transaksi secara online mendorong tumbuhnya pengusaha-pengusaha online skala kecil di seluruh wilayah Indonesia (Hoga Saragih, 2012).

\section{METODE PELAKSANAAN}

Langkah-langkah yang dilakukan dalam melaksanakan inovasi penjualan batik Tanjungbumi berbasis aplikasi online untuk mengatasi permasalahan masyarakat mitra antara lain:

\section{Identifikasi masalah}

Sebagian besar masyarakat Paseseh masih termasuk dalam masyarakat dengan ekonomi menengah ke bawah dan hanya bekerja sebagai pengrajin batik. Untuk meningkatkan taraf hidup masyarakat yaitu dengan cara memasarkan batik tanjung bumi secara online agar batik dapat dipasarkan dengan cepat dan efektif guna menambah pengetahuan menggunakan tekhnologi dan mempercepat hasil yang didapat sehingga dapat mengentaskan kemisikinan yang menjadi tujuan akhirnya. 


\section{Roadmap program}

Gambar 1. Roadmap Abdimas

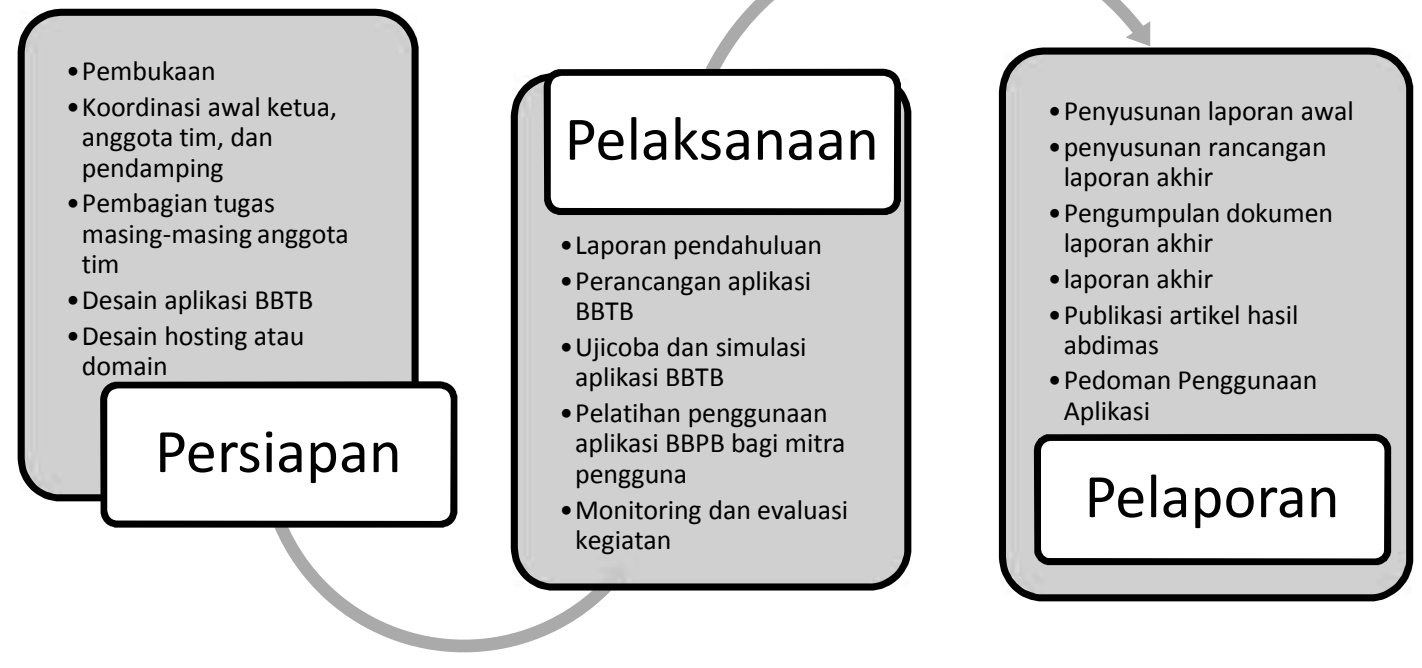

\section{Persiapan program}

Kegiatan yang dilakukan pada tahap persiapan program antara lain:

1. Koordinasi awal ketua, anggota tim, dan pendamping

Pada tahap ini ketua mengkoordinasi anggota tim yang didampingi pendamping untuk membicarakan hal-hal yang akan dilakukan.

2. Pembagian Tugas masing-masing anggota tim

Ketua tim mengarahkan seluruh anggota tim sekaligus pembagian tugas mengenai hal-hal yang akan dibuat.

3. Desain aplikasi BBTB

Pada tahap ini, pendamping mendampingi ketua dan anggota untuk mendesain aplikasi sekaligus menilai aplikasi yang telah dibuat.

4. Desain hosting/domain

Pada tahap ini, pendamping mendampingi ketua dan anggota untuk mendesain hosting/domain sekaligus menilai hosting/domain yang telah dibuat.

\section{Pelaksanaan program}

1. Laporan pendahuluan

Ketua tim melakukan koordinasi kepada Kepala Desa mengenai waktu pelaksanaan pengabdian masyarakat

2. Perancangan aplikasi BBTB

Ketua tim dan anggota merancang aplikasi BBTB dibantu oleh tenaga ahli bidang IT

3. Ujicoba dan simulasi aplikasi BBTB 
Ketua tim dan anggota melakukan ujicoba dan simulasi aplikasi BBTB dibantu oleh tenaga ahli bidang IT

4. Pelatihan penggunaan aplikasi BBPB bagi mitra pengguna

Pada tahap ini seluruh anggota tim melatih mitra untuk belajar menggunakan aplikasi BBTB sebagai alat transaksi jual beli

5. Monitoring dan evaluasi kegiatan

Pada tahap ini seluruh anggota tim mengumpulkan informasi tentang efektivitas penggunaan aplikasi terhadap aktivitas jual beli batik Tanjungbumi. Pada akhir kegiatan, seluruh anggota tim melakukan evaluasi kegiatan untuk melengkapi laporan kegiatan program pengabdian kepada masyarakat.

\section{Pelaporan program}

1. Penyusunan laporan awal

Tahap ini dilakukan setelah menyelesaikan pelatihan, anggota tim akan menyusun hasil program kegiatan pengabdian kepada masyarakat.

2. penyusunan rancangan laporan akhir

Setelah menyusun hasil kegiatan pengabdian kepada masyarakat, anggota tim akan melakukan diskusi mengenai rancangan laporan.

3. Pengumpulan dokumen laporan akhir

Ketua dan seluruh anggota tim mengumpulkan seluruh dokumen yang berkaitan dengan penyusunan laporan akhir pengabdian kepada masyarakat.

4. laporan akhir

ketua dan seluruh anggota tim menyusun laporan akhir pengabdian kepada masyarakat.

5. Publikasi artikel hasil abdimas

Salah satu luaran hasil pengabdian kepada masyarakat. adalah publikasi artikel pada jurnal pengabdian masyarakat yang terakreditasi Sinta 4.

6. Pedoman Penggunaan Aplikasi

Aplikasi penjualan berbasis online dilengkapi dengan pandoman penggunaan agar mudah dipahami oleh mitra.

7. Penyelesaian administrasi laporan

Ketua tim beserta seluruh anggota melengkapi seluruh administrasi yang dibutuhkan untuk laporan pengabdian kepada masyarakat.

\section{Subsitusi IPTEK dan pelatihan}

IPTEK yang akan dilakukan yaitu pembuatan aplikasi khusus bagi para pengrajin batik di Desa Paseseh Kecamatan Tanjangbumi Kabupaten Bangkalan. Aplikasi ini diberi nama Bumi Batik Tanjungbumi (BBTB). Aplikasi BBTB merupakan Aplikasi Jual Beli Onlie yang dapat di download melalui smartphone. Aplikasi ini dirancang untuk memudahkan pengusaha batik Tanjungbumi untuk memasarkan produknya secara online kepada masyarakat luas dan melakukan transaksi jual beli secara online dengan metode pembayaran secara online maupun offline. Aplikasi BBTB dilengkapi dengan beberapa fitur, antara lain info produk, kategori produk, keranjang, favorite dan pesanan. Untuk menikmati fitur 
yang disediakan dalam aplikasi BBTB, pengguna harus memiliki akun dengan cara mendaftar pembuatan akun dalam aplikasi tersebut.

\section{HASIL DAN PEMBAHASAN}

Hasil kegiatan pengabdian kepada masyarakat adalah aplikasi penjualan berbasis online dan memiliki beberapa fitur yang memudahkan pengguna menjual batik Tanjungbumi secara luas melalui jejaring online dan calon pembeli juga dapat memperoleh informasi yang cepat dan akurat. Aplikasi penjualan berbasis online yang dirancang diberima nama BBTB (Bumi Batik Tanjungbumi).

Berdasarkan hasil studi pendahuluan permasalahan masyarakat desa Paseseh Kecamatan Tanjungbumi Kabupaten Bangkalan, maka diperoleh beberapa masalah pokok penjualan batik Tanjungbumi, antara lain:

1. Rendahnya pengunjung atau calon pembeli dikarena masa pandemi covid 19

2. Terbatasnya akses penjualan batik kepada masyarakat luas

3. Penjualan batik masih dilakukan secara konvensional

4. Rendahnya pendapat masyarakat pengrajin batik

5. Belum tersedianya aplikasi online yang mewadahi penjualan batik Tanjungbumi

Mengacu pada permasalahan di atas, maka solusi konkrit yang ditawarkan kepada mitra adalah aplikasi penjualan batik Tanjungbumi berbasis online. Aplikasi online yang diberi nama Bumi Batik Tanjungbumi (BBTB) memiliki beberapa fitur yang memudahkan mitra melakukan transkasi jual beli batik Tanjungbumi secara online. Fitur-fitur tersebut antara lain:

\section{Tentang}

Fitur tentang berisi informasi tentang produk-produk batik Tanjungbumi. Batik Tanjungbumi dibedakan menjadi beberapa kategori. Pertama, kategori batik Tanjungbumi berdasarkan model dan cara pembuatannya antara lai: 1) Gentongan, 2) Sarimbit, dan 3) Biasa. Kedua, kategori batik Tanjungbumi berdasarkan motif atau corak, antara lain: 1) Peri kecil, 2) Kucing duduk, 3) Daun mimba, 4) Burung merak, 5) Perahu, 6) Rongterong, 7) Ramo, 8) Perkaper, 9) Serat kayu, 10) Kecambah, dan 11) Sisik.

\section{Hubungi}

Fitur hubungi berisi tentang kontak yang bisa dihubuingi oleh calon pembeli. Kontak hubung meliputi nomor handphone, whatsapp, instagram, facebook, dan telegram.

\section{Pembayaran}

Fitur pembayaran merupakan metode transaksi yang bisa dipilih oleh calon pembeli. Pembayaran dapat dilakukan secara langsung, atau melalui mobile banking atau aplikasi pembayaran online lainnya.

\section{Ongkir}

Fitur ongkir merupakan fasilitas penghantara produk melalui jasa pengiriman logistik. 


\section{Favorite}

Fitur favorite menampilkan produk-produk yang banyak dibeli oleh para pembeli. Produk dari berbagai kategori yang banyak dibeli akan secara otomatif tampil pada menu favorite. Menu favorit juga dilengkapi dengan jumlah produk yang terjual disertai informasi produk secara lengkap.

\section{Keranjang}

Calon pembeli tidak harus langsung membeli produk-produk batik Tanjungbumi, namun juga bisa menyimpang di menu keranjang. Menu keranjang bisa dimanfaatkan oleh calon pembeli sebagai produk yang rencananya akan dibeli atau melakukan analisa produk sejenis.

\section{Pesanan}

Produk batik Tanjuungbumi yang pasti akan dibeli oleh pelanggan akan masuk ke dalam menu pesanan. Setelah masuk menu pesanan, calon pembeli dapat memilih metode transaksi yang diinginkan.

\section{Akun}

Untuk membeli produk batik Tanjungbumi melalui aplikasi BBTB, calon pembeli diharuskan membuat akun terlebih dahulu. Manfaat memiliki akun, selain memudahkan calon pembeli melakukan transaksi, calon pembeli akan memperoleh informasi terupdate tentang produk-produk terbaru Batik Tanjungbumi.

Pemilihan aplikasi berbasis online sebagai metode transaksi jual beli batik Tanjungbumi didasarkan pada beberapa alasan, yaitu tren belanja online semakin merebah di seluruh Indonesia. hal tersebut disambut oleh seluruh lapisan masyarakat terima UMKM untuk meningkatkkan akses pemasaran dan penjualan yang lebih luas. alasan masyarakat Indonesia berbelanja secara online. Sebanyak $63 \%$ menunjukkan bahwa alasan orang Indonesia berbelanja online adalah practicality, atau kepraktisan (Sitorus, 2019). Saat ini kebutuhan hidup masyarakat mudah didapat tanpa harus pergi ke tempat pembelanjaan. Masyarakat dapat mengakses berbagai kebutuhan melalui smartphone yang berbasis android. Hanya dengan membuka handphone yang terhubung melalui jaringan internet, masyarakat bisa mengkases berbagai informasi yang dibutuhkan. Saat ini internet menjadi unggulan bagi para pebisnis dalam usaha memenangkan persaingan bisnis (Hoga Saragih, 2012). Hal ini yang juga coba dilakukan oleh para pengusaha batik Tanjungbumi, mereka memanfaatkan internet sebagai media jual beli berbasis online melalui aplikasi BBTB. Pemasaran produk usaha secara online menjadi tren dimana-mana dikarenakan pemanfaatan teknologi berbasis IT yang tepat guna dan mendukung pemasaran produk melalui teknologi di bidang internet (Putra, 2013).

Batik tanjungbumi memiliki kualitas bahan dan mekanisme produksi yang sangat baik. Batik tanjungbumi dibuat dengan kain yang terbaik dan bahan yang dijadikan pewarna berasal dari ligkungan sekitar yang bersifat alam, yaitu daundaunan dan akar tanaman. Hal tersebut yang menjadi keunggulan produk batik 
Tanjungbumi karena memiliki kualitas produk yang sangat baik dan hal tersebut juga menjadi faktor kepuasan para calon konsumen dalam membeli produk batik Tanjungbumi. Bagi konsumen, belanja online akan sangat tinggi jika mereka merasa puas akan kualitas jasa dari sistem penjualan online di situs tersebut (Hoga Saragih, 2012). Minat seseorang untuk kembali berbelanja sangat dipengaruhi oleh kenyamanan, kepuasan serta persepsi harga yang diberikan oleh suatu toko (Hoga Saragih, 2012).

Pembuatan aplikasi jual beli berbasis online bertujuan untuk mengembangkan UMKM batik Tanjungbumi. Usaha Mikro, Kecil dan Menengah (UMKM) mempunyai peran penting dan strategis dalam pembangunan ekonomi nasional. Selain berperan dalam pertumbuhan ekonomi dan penyerapan tenaga kerja, UMKM juga berperan dalam mendistribusikan hasil-hasil pembangunan (Syahputri, 2018). Peningkatan daya saing UMKM juga dapat mendorong daya beli masyarakat sehingga mampu mendorong kemajuan perekonomina nasional. Aplikasi Bumi Batik Tanjungbumi merupakan awal perubahan dan inovasi penjualan batik Tanjungbumi berbasis online. Hal tersebut juga harus diikuti dengan peningkatan kuaitas dan pelayanan terhadap konsumen. Pengusaha akan memperoleh dukungan dari konsumen melalui kepercayaan konsumen dalam membuat keputusan untuk membeli produk yang diinginkan sebagai bentuk dukungan konsumen terhadap upaya memperoleh produk yang diinginkan (Sugara, 2017).

Untuk memanjakan konsumen dalam mengenal dan membeli produk batik Tanjungbumi, aplikasi Bumi Batik Tanjungbumi dilengkapi dengan fitur-fitur penjualan online yang sangat bagus. Melalui fitur tersebut, calon konsumen dapat memperoleh kemudahan untuk mengenal produk-produk batik Tanjungbumi. Keputusan konsumen untuk membeli suatu produk didasarkan pada pencarian informasi melalui ftur-fitur apliksi yang dapat diakses secara online sehingga konsumen dapat mengenal spesifikasii produk dan jasa. Kemudian produk dan jasa yang dibeli dan digunakan oleh konsumen sebagai bentuk evaluasi terhadap daya guna produk serta membuang produk jika sudah tidak digunakan (Sugara, 2017). Kemudahan tidak hanya dalam hal mengenal produk batik Tanjungbumi, namun juga kemudahan dalam melakukan transaksi jual beli online. Persepsi kemudahan berimplikasi pada perilaku, semakin tinggi persepsi seseorang tentang kemudahan penggunaan sebuah sistem, semakin tinggi juga tingkat pemanfaatan teknologi informasi (Sitorus, 2019).

\section{SIMPULAN}

Aplikasi Bumi Batik Tanjungbumi (BBTB) merupakan solusi atas rendahnya tingkat penjualan pengrajin batik Desa Paseseh Kecamatan Tanjungbumi Kabupaten Bangkalan. Aplikasi BBTB dilengkapi dengan berbagai fitur yang memanjakan para calon pembeli. Fitur-fitur tersebut antara lain: 1) tentang, 2) hubungi, 3) pembayaran, 4) ongkir, 5) favorit, 6) keranjang, 7) pesanan, dan 8) 
akun. Melalui aplikasi berbasi online, pengusaha Batik Tanjungbumi dapat memasarkan produknya lebih luas secara online dan melakukan transaksi jual beli secara online pula yang dapat diakses oleh masyarakat luas. Disamping itu, aplikasi BBTB mampu meningkatkan penghasilan pengusaha Batik Tanjungbumi.

\section{UCAPAN TERIMA KASIH}

Ucapan terima kasih kami sampaikan kepada Kemeterian Pendidikan dan Kabudayan Republik Indonesia (Kemendikbud) yang telah berkenan menerima dan mendanai proposal yang kami ajukan. Program hibah sangat bermanfaat sekali bagi para pengusaha batik Tanjungbumi di masa pandemi covid 19. Para pengusaha batik dapat tepat melakukan transaksi secara online, baik memasarkan produk maupun melakukan transaksi jual beli. Program ini harapannya nanti dapat meningkatkan taraf hidup dan kesejahteraan masyarakat Desa Paseseh Kecamatan Tanjungbumi Kabupaten Bangkalan.

\section{DAFTAR RUJUKAN}

Hoga Saragih. (2012). Pengaruh Intensi Pelanggan dalam Berbelanja online Kembali Melalui Media Teknologi Informasi Forum Jual Beli (FJB) Kaskus. Journal of Information Systems, 8(2), 100-112.

Languyu Novianto. (2015). Kedudukan Hukum Penjual dan Pembeli dalam Bisnis Jual Beli Online. Lex Et Societatis, 3(9), 94-100.

Putra, P. K. (2013). Aplikasi Toko Tas Online Berbasis Online. Jurnal Dimensi Teknik Elektro, 1(1), 12-17.

Sitorus, S. D. (2019). Pengaruh Persepsi Kemudahan, Persepsi Risiko, dan Kepercayaan Konsumen terhadap Minat Beli Online (Studi pada Mahasiswa Pengguna Aplikasi Jual Beli Online Carousell. Jurnal Administrasi Bisnis (JAB), 73(1), 141-150.

Sugara, A. (2017). Analisis Kepercayaan dan Kepuasan terhadap Penggunaan Sistem Transaksi Jual Beli Online (Studi Pada Konsumen "Z"). Jurnal Administrasi Bisnis (JAB), 52(1), 8-15.

Syahputri, W. (2018). Desain Prototipe Sistem Jual Beli Online Produk Umkm Bengkalis Berbasis Android. Jurnal Ilmiah Ilmu Komputer, 4(1), 27-33. 
90 J-Abdipamas, Vol. 4, No. 2, Oktober, 2020 